\title{
Quantitative real-time PCR for detecting germination of Heterosigma akashiwo and Chattonella subsalsa cysts from Delaware's Inland Bays, USA
}

\author{
Kevin J. Portune ${ }^{1}$, Kathryn J. Coyne ${ }^{1}$, David A. Hutchins ${ }^{1,2}$, Sara M. Handy ${ }^{1,3}$, \\ S. Craig Cary ${ }^{1,4, *}$
}

${ }^{1}$ College of Marine and Earth Studies, University of Delaware, 700 Pilottown Rd., Lewes, Delaware 19958, USA

${ }^{2}$ Present address: Department of Biological Sciences, University of Southern California, 3616 Trousdale Parkway, Los Angeles, California 90089, USA

${ }^{3}$ Present address: Department of Cell Biology and Molecular Genetics, 2103 Biosciences Research Building, University of Maryland, College Park, Maryland 20742, USA

${ }^{4}$ Present address: Department of Biological Sciences, University of Waikato, Private Bag 3105, Hamilton, New Zealand

\begin{abstract}
Cyst germination of strains of the harmful algal species Heterosigma akashiwo and Chattonella subsalsa (Raphidophyceae) from Delaware's (USA) Inland Bays was studied both in the field and laboratory during the spring and early summer seasons. Quantitative real-time PCR was employed for detection and quantification of cells in natural sediments and of germinated vegetative cells in the water column. Temperature, salinity, and dissolved nutrient concentrations were examined in field mesocosm experiments to identify physicochemical factors associated with germination, while the effects of temperature and light on germination were examined in laboratory experiments. We detected and monitored a wide range of cyst abundances of $H$. akashiwo (from 164 to 2820 cysts $\mathrm{cm}^{-3}$ wet sediment) and C. subsalsa cysts (from 2 to 135 cysts $\mathrm{cm}^{-3}$ wet sediment) in environmental sediments. Germinated $H$. akashiwo cells were detected in situ after temperatures reached $15^{\circ} \mathrm{C}$. However, in laboratory studies, H. akashiwo germination occurred at even lower temperatures $\left(10^{\circ} \mathrm{C}\right)$, which was considerably lower than typical germination temperatures from similar Japanese strains. In contrast, a temperature of $20^{\circ} \mathrm{C}$ stimulated C. subsalsa germination in both field and laboratory studies, although germination still occurred at low temperatures $\left(10^{\circ} \mathrm{C}\right)$. The presence or absence of light did not affect the germination of $C$. subsalsa. The low quantities of detected vegetative cells from cyst germination for both $H$. akashiwo and $C$. subsalsa suggest the inoculation of a small number of vegetative cells into the water column during the spring and early summer months.
\end{abstract}

KEY WORDS: Raphidophytes · Cyst germination - Quantitative real-time PCR · Heterosigma akashiwo $\cdot$ Chattonella subsalsa

\section{INTRODUCTION}

Heterosigma akashiwo and Chattonella spp. are unicellular flagellated algae (class Raphidophyceae) that are capable of forming high-density blooms. These algae have received international attention by causing massive fish kills, resulting in millions of dollars of loss to the aquaculture industry (Okaichi 1989, Park et al. 1989, Honjo 1993). Raphidophytes have life cycles that alternate between non-motile benthic cysts and vegetative planktonic stages (Imai et al. 1998). The resting cyst stages of raphidophytes offer protection from less favorable conditions, and their dispersal into the water column as vegetative cells may also determine where 
future blooms occur (Imai \& Itoh 1987, Imai \& Itakura 1999). Several distinct overwintering stages have been reported for $H$. akashiwo and described by Shikata et al. (2007) as either benthic stage cells that aggregate into masses encapsulated by a mucus layer (Tomas 1978, Yamochi 1989), resting cells (Han et al. 2002), or true cysts (Imai et al. 1993). True cysts of $H$. akashiwo are smaller and have fewer chloroplasts than benthic stage cells (Smayda 1998) and require a dormancy period of at least 2 wk before germination can occur (Itakura et al. 1996), while resting cells have no dormancy period (Han et al. 2002). While only true cysts have been identified in natural sediments (Imai et al. 1993) and resting cells are likely caused by temporary adverse environmental conditions (Han et al. 2002), we consider $H$. akashiwo cells found living in sediments to be true cysts, similar to Shikata et al. (2007). Cyst stages of Chattonella spp. (C. marina, C. antiqua, C. ovata) are well documented (Imai et al. 1998 and references therein, Yamaguchi et al. 2008), although currently we are not aware of any studies on the cysts of C. subsalsa. It has been suggested that $H$. akashiwo is haploid in both vegetative and resting stages (Han et al. 2002). Conversely, C. antiqua and C. marina are both diploid in the vegetative stage (2C to $4 \mathrm{C}$ ), but haploid in their resting cyst stage (Yamaguchi \& Imai 1994), while the ploidy level of C. subsalsa is currently unknown.

In laboratory experiments, temperature has been shown to be an important factor in the germination of Chattonella antiqua, C. marina, and Heterosigma akashiwo, with optimal temperature ranges between 20 and $25^{\circ} \mathrm{C}$ (Imai et al. 1984a, 1989, 1991, Imai \& Itoh 1987, Imai \& Itakura 1999, Han et al. 2002). Availability and abundance of light was also found to be critical for the successful germination of certain strains of $H$. akashiwo (Han et al. 2002), while light was not required for the germination of other strains of $H$. akashiwo and Chattonella (Imai et al. 1984a, 1996, Shikata et al. 2007). Mature H. akashiwo cysts can also germinate independently of temperature and light if suspended in seawater, although low temperature and light severely reduce cell survival after germination (Shikata et al. 2007).

Since the year 2000, the raphidophytes Heterosigma akashiwo and Chattonella subsalsa have consistently been detected from multiple sites within the coastal waters of Delaware's Inland Bays, USA (Whereat 2002-2006). Delaware's Inland Bays (DIBs) include 3 shallow bodies of water: Rehoboth Bay, Indian River Bay, and Little Assawoman Bay. During the winter, water temperatures and salinities as low as $4^{\circ} \mathrm{C}$ and 0 psu can occur in some areas (Whereat 2002-2006). Early spring (March/April) water temperatures can fluctuate between 3.5 and $21^{\circ} \mathrm{C}$ (mean \pm SD, $11.8 \pm$ $3.7^{\circ} \mathrm{C}$ ), and salinity can range from 2.8 to 28 (mean \pm SD, $12.4 \pm 6.7$ ) (Whereat 2002-2006). Initial detections of vegetative cells of $H$. akashiwo and C. subsalsa have been consistently observed in the water column of the DIBs in May and June, respectively, and persist until September/October, at which time they become undetectable in the water for the remainder of the year (Whereat 2002-2006).

Because of the difficulties associated with the isolation, identification, and enumeration of algal cysts within natural sediments, most work on the germination of cyst-forming harmful phytoplankton species has been limited to laboratory culture-based inference methods, such as the most probable number method (Imai et al. 1984b, 1989, Imai \& Itoh 1987, Imai \& Itakura 1999). However, this method only gives an estimate of the total number of cysts present in the sediment based on the concentrations of vegetative cells that have germinated into the water column, and thus has the potential to underestimate (Anderson et al. 2003) or overestimate the actual number of cysts in sediments. Traditional microscopic methods for identifying and enumerating cells also have substantial limitations in enumerating low quantities of cells. Therefore, the application of highly sensitive molecular tools such as quantitative real-time PCR (QPCR) is well suited for examining phytoplankton cyst germination through direct identification and enumeration of cysts and vegetative cells of algae.

Detection of initial germination events of raphidophytes is important for early monitoring strategies in areas at risk of harmful algal blooms and may assist potential mitigation and control of these harmful algae before they can develop into bloom concentrations. We hypothesized that initial seasonal cyst germination events in the DIBs may be controlled by physical environmental stimuli and that increases in temperature and light would stimulate cyst germination. Here, we describe the application of molecular-based quantitative tools (QPCR) to examine the interactive effects of temperature and light on the germination of natural populations of Heterosigma akashiwo and Chattonella subsalsa cysts from the DIBs.

\section{MATERIALS AND METHODS}

Field experiments. To examine the germination of natural cysts from environmental sediments, separate field experiments were conducted for Heterosigma akashiwo, referred to as Field Experiment 1 (FE-1), and for Chattonella subsalsa (FE-2), beginning March 17 and May 9, 2005, respectively. Experiments were conducted for 28 d off local docks located in Love Creek, a tributary of Rehoboth Bay, Delaware, and in a 
man-made canal in Holly Terrace Acres in Indian River Bay, Delaware (Fig. 1), respectively, for FE-1 and FE-2. To collect vegetative cells that germinated from sediments into the overlying water column, triplicate germination mesocosms for each field experiment (designated A, B, and C) were installed $60 \mathrm{~cm}$ apart over sediment within $1 \mathrm{~m}$ of boat docks at each site. All mesocosms were continually covered by water that ranged from 2 to $3 \mathrm{~m}$ in depth, and light levels were 515 and $380 \mu \mathrm{E}$ for FE-1 and FE-2, respectively. Each mesocosm consisted of a clear plastic container $(47 \mathrm{~cm}$ $\times 35 \mathrm{~cm} \times 23 \mathrm{~cm}$ ), the open end of which was buried into the sediment roughly 5 to $7.5 \mathrm{~cm}$ deep, completely encasing 301 of water overlying the sediment (Fig. 2A). Water samples of 11 were incrementally collected from the mesocosms at 2 to $5 \mathrm{~d}$ intervals by repeated $60 \mathrm{ml}$ samplings using a syringe attached to Nalgene tubing extending into each mesocosm (Fig. 2A). Since the mesocosms were only open to the sediments, sampled water was replaced by flow through the sedimentwater interface under the mesocosms. Water samples were collected from each germination mesocosm between 13:00 and 15:00 $\mathrm{h}$ to ensure that vertically migrating $H$. akashiwo and C. subsalsa would be close to the sampling port, as these species are found nearer the surface during early afternoon (Handy et al. 2005). One liter of water was also collected from the water column outside of each mesocosm using a bilge pump. Water temperature and salinity were measured for each water sample collected from the mesocosm before being brought back to the laboratory for analysis.

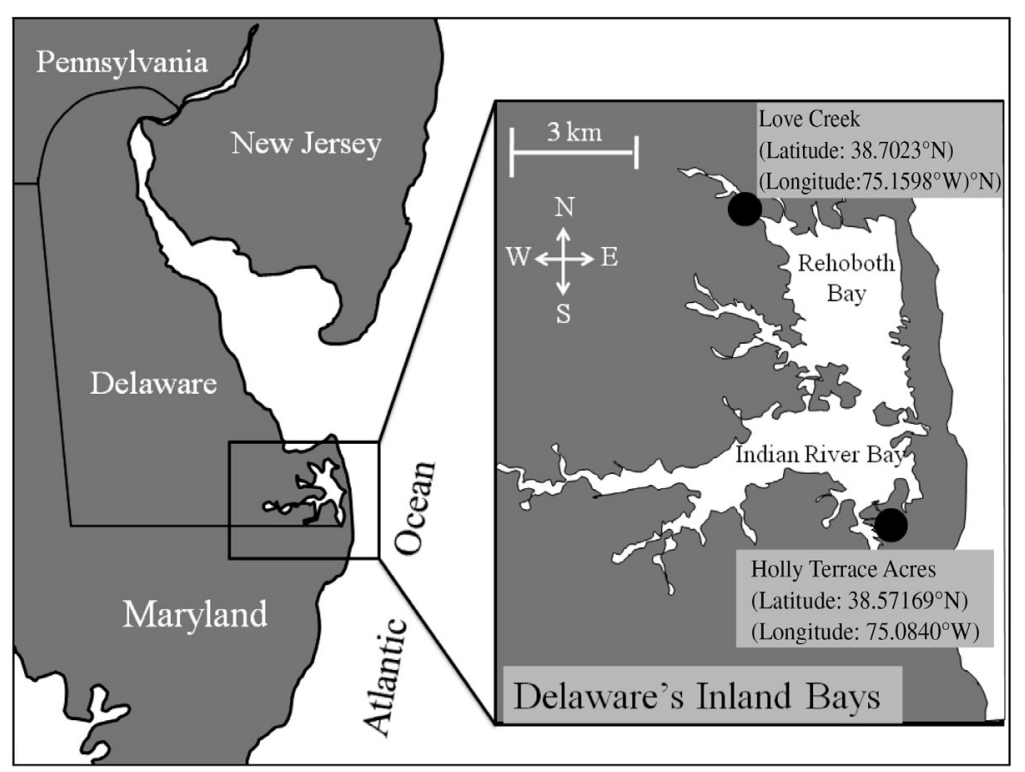

Fig. 1. Delaware's Inland Bays, USA, including sampling sites at Love Creek and Holly Terrace Acres for field experiments
To examine the initial cyst abundances of Heterosigma akashiwo and Chattonella subsalsa in the sediments of each field site, respectively, 3 cores for FE-1 and 6 for FE-2 were collected at $30 \mathrm{~cm}$ intervals beside and between the secured mesocosms, directly after the mesocosms were installed into the sediment. The cores were collected in sterile $60 \mathrm{ml}$ plastic syringes (Becton, Dickinson) using a push-core sampling device (Fig. 2B). A 2-way valve attached to the leading end of the Nalgene tubing running through the push-core device was opened to allow water to escape only when the corer was pushed into the sediment. The valve was then closed, sealing the system and preventing air from entering the line, thus allowing the sediment core ( $\sim 4$ to $8 \mathrm{~cm}$ long) to be retained in the $60 \mathrm{ml}$ syringe when removed from the sediment. On recovery, the open bottom of the syringes were plugged with silicone stoppers, removed from the PVC pipe, and transported to the laboratory in coolers for immediate sectioning and DNA extraction.

Laboratory experiments. Separate laboratory experiments were conducted concurrently with field experiments for Heterosigma akashiwo, referred to as Laboratory Experiment 1 (LE-1), and for Chattonella subsalsa (LE-2). Since large volumes of sediment were required for the laboratory experiments, 6 sediment cores were collected for each laboratory experiment with a large-diameter push-core sampling device, consisting of a metal pole (240 cm length) connected to a detachable sterile standard acrylic push core $(8 \mathrm{~cm}$ diameter). Sediment cores were taken $\sim 25 \mathrm{~cm}$ apart from around the submerged mesocosms in FE-1 and

FE-2 and transported in coolers to the laboratory for immediate analysis. The cores were taken at night to avoid exposure to light, which could influence germination, and all work in the laboratory was performed under red light (680 nm). For each experiment, the top $2 \mathrm{~cm}$ of sediment from each of the 6 cores was isolated and thoroughly mixed together to create a homogenous sediment sample. Six wet sediment sub-samples ( $2 \mathrm{~g}$ each) from the mixed sediment were used for further analysis to determine initial cyst concentrations of $H$. akashiwo and C. subsalsa.

To determine the effects of temperature and light on the germination of Heterosigma akashiwo and Chattonella subsalsa, a $2 \times 2$ factorial design was set up in the laboratory. Twenty gram aliquots of homogenously mixed wet sediment were added to 12 sterile $250 \mathrm{ml}$ Erlenmeyer flasks and covered with $200 \mathrm{ml}$ of $0.2 \mu \mathrm{m}$ filtered seawater collected from each site 


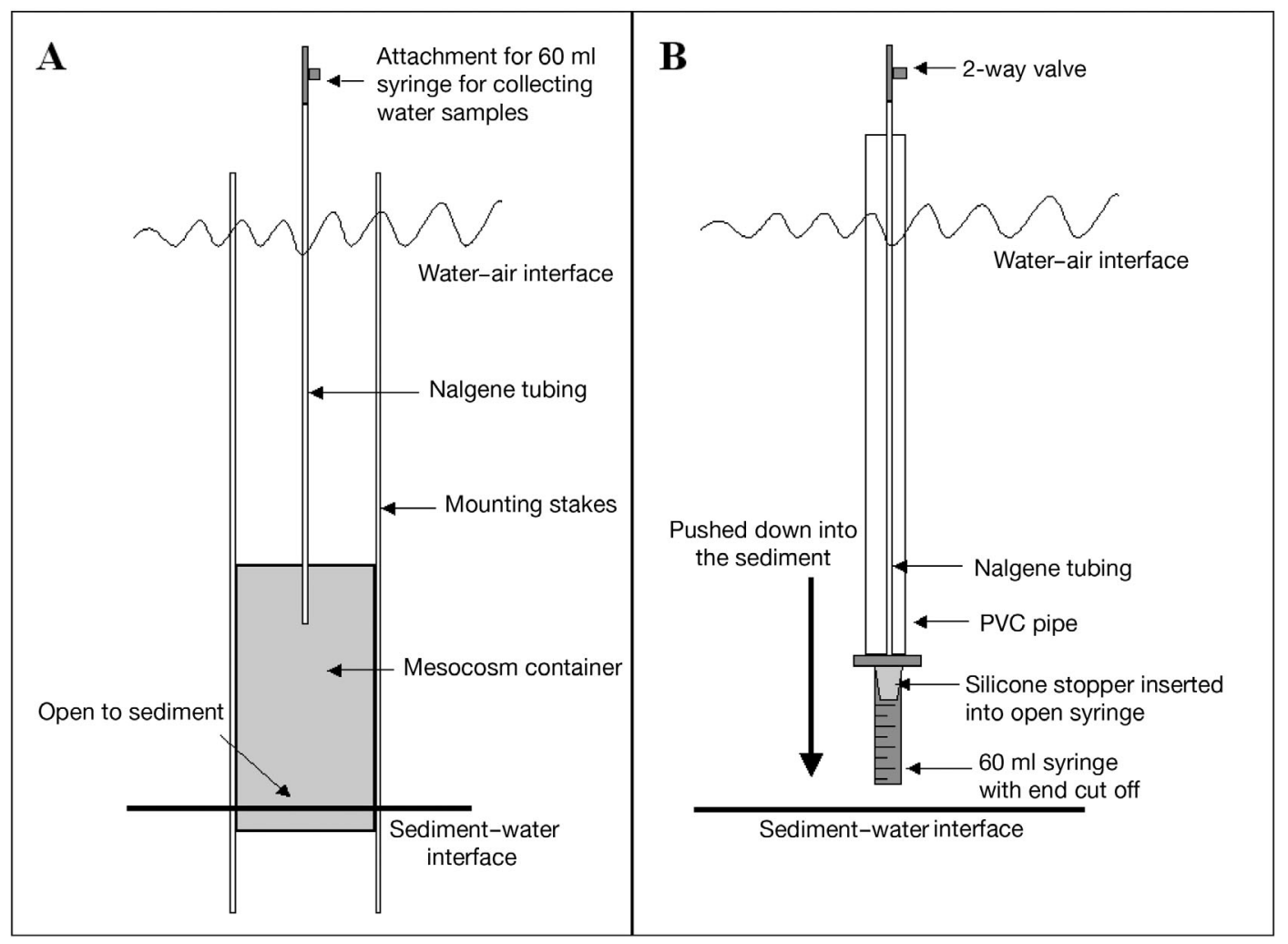

Fig. 2. (A) Mesocosm design for field experiments. Mesocosms were submersed under water and buried in natural sediments using mounting stakes, allowing water exchange only between the mesocosm container and the sediment. Water samples were collected using a $60 \mathrm{ml}$ syringe attached to Nalgene tubing that entered through the top of the mesocosms. (B) Sediment pushcore sampling device: $60 \mathrm{ml}$ syringes (with the bottom cut off) were attached to a PVC pipe and were fitted with a 1-hole silicone stopper that allowed the Nalgene tubing to enter into the top of the syringe. When the syringe was pushed into the sediment, air was allowed to escape out through the top of the Nalgene tubing. A 2-way valve attached to the open end of the Nalgene tubing was then closed off to create a vacuum and keep the sediment core in the syringe as it was pulled out of the sediment

(salinities of 14 and 25 for LE-1 and LE-2, respectively). Triplicate flasks were randomly selected and immediately subjected to 4 treatments of light and temperature: 10 and $20^{\circ} \mathrm{C}$ under $55 \mu \mathrm{mol}$ photons $\mathrm{m}^{-2} \mathrm{~s}^{-1}(12 \mathrm{~h}$ light:12 h dark cycle), or 10 and $20^{\circ} \mathrm{C}$ under total darkness. Water samples containing potentially germinated vegetative cells were collected 11,21 , and $30 \mathrm{~d}$ after the start of the experiment for LE-1 (H. akashiwo) and 5, 11, 15 and $22 \mathrm{~d}$, for LE-2 (C. subsalsa). At each sampling point, $30 \mathrm{ml}$ of overlying water was collected from each flask with a sterile glass pipette. Then, $30 \mathrm{ml}$ of $0.2 \mu \mathrm{m}$ filtered seawater (of the same salinity for each respective experiment) was replaced so as to not disturb the sediment after each sampling, thus diluting the water by $15 \%$.

DNA extraction from water and sediment samples. All water samples from field and laboratory experiments were filtered onto $3 \mu \mathrm{m}$ polycarbonate filters (Millipore). The filters were submersed in $700 \mu \mathrm{l}$ of CTAB buffer (100 mM Tris- $\mathrm{HCl}[\mathrm{pH} 8], 1.4 \mathrm{M} \mathrm{NaCl}$, $2 \%[\mathrm{w} / \mathrm{v}]$ cetyltrimethylammonium bromide [CTAB],
$0.4 \%$ [v/v] $\beta$-mercaptoethanol, 1\% [w/v] polyvinylpyrollidone, $20 \mathrm{mM}$ EDTA; [Dempster et al. 1999]) amended with $20 \mathrm{ng} \mathrm{ml}^{-1}$ pGEM plasmid (Promega) as an internal QPCR standard (Coyne et al. 2005). DNA extractions were performed as described by Coyne et al. (2001). The filtrate was filtered through a $0.2 \mu \mathrm{m}$ polycarbonate filter and stored at $-20^{\circ} \mathrm{C}$ for nutrient examination. Each $0.2 \mu \mathrm{m}$ filtered water sample was measured in triplicate for phosphate $\left(\mathrm{PO}_{4}{ }^{3-}\right)$, nitrate + nitrite $\left(\mathrm{NO}_{\mathrm{x}}{ }^{-}\right)$, and ammonium $\left(\mathrm{NH}_{4}^{+}\right)$with an autoanalyzer (Alpkem).

Since phytoplankton cyst germination is likely to proceed from sediments at the sediment-water interface, $2 \mathrm{~g}$ of wet sediment was isolated from the top $2 \mathrm{~cm}$ of each sediment core used for DNA extraction in field experiments. For laboratory experiments, 6 wet sediment sub-samples ( $2 \mathrm{~g}$ each) from homogenously mixed sediment were used for DNA extractions. Extractions were carried out in sterile, $50 \mathrm{ml}$ polycarbonate screw-cap tubes, with $5 \mathrm{ml}$ of amended CTAB buffer added, as described by Coyne et al. (2001), mod- 
ified by including a $65^{\circ} \mathrm{C}$ shaking water bath step prior to chloroform extraction.

Molecular detection and quantification of Heterosigma akashiwo and Chattonella subsalsa cells. Quantification of $H$. akashiwo and C. subsalsa cells was performed by a Taqman-based QPCR assay on an ABI Prism 7500 Sequence Detection System (Applied Biosystems). H. akashiwo and C. subsalsa speciesspecific primers and probes targeting the 18S rRNA gene were used to identify and enumerate each species (Coyne et al. 2005). Triplicate $10 \mu$ l reactions for each sample consisted of $5 \mu$ l of Taqman Universal Master Mix (Applied Biosystems), $0.9 \mu \mathrm{M}$ of each primer, $0.2 \mu \mathrm{M}$ Taqman probe, and $1 \mu \mathrm{l}$ of diluted DNA template $(0.35$ to $20 \mathrm{ng}$ DNA for water samples and 1.86 to $10.1 \mathrm{ng}$ DNA for sediment samples). The internal DNA plasmid standard in each sample was amplified using the primers M13 F and pGEM R and reported using the pGEM probe, as described by Coyne et al. (2005). Reaction conditions consisted of $2 \mathrm{~min}$ at $50^{\circ} \mathrm{C}, 10 \mathrm{~min}$ at $95^{\circ} \mathrm{C}$, followed by 50 to 55 cycles of $15 \mathrm{~s}$ at $95^{\circ} \mathrm{C}$ and $1 \mathrm{~min}$ at $60^{\circ} \mathrm{C}$. Since QPCR cannot distinguish whether a detected cell is vegetative or a cyst, assumptions are made such that cells buried in sediment samples are considered cysts, while cells detected in water samples are considered vegetative cells that germinated into the water column.

Preparation of a standard curve for quantification from QPCR. DIB isolates Heterosigma akashiwo (CCMP 2393, isolated from Rehoboth Bay, DE, USA) and Chattonella subsalsa (CCMP 2191 isolated from Indian River Bay, DE, USA) were maintained in $f / 2$ medium (Guillard 1975) under a $12 \mathrm{~h}$ light:12 h dark cycle at $23^{\circ} \mathrm{C}$. Cell counts were performed using triplicate $1 \mathrm{ml}$ aliquots taken from exponentially growing cultures using a Spears-Levy hemocytometer. Standards for QPCR quantification of $H$. akashiwo and C. subsalsa cells were generated by spiking $100 \mathrm{ml}$ of each culture into $900 \mathrm{ml}$ of environmental seawater free of any $H$. akashiwo or C. subsalsa cells. The water was filtered onto a $3 \mu \mathrm{m}$ polycarbonate filter, and DNA was extracted as described above. Ten-fold dilutions of the extracted DNA were included in each QPCR run to generate standard curves for the target (H. akashiwo or C. subsalsa) and internal DNA plasmid (pGEM). Mean concentrations of target and pGEM DNA in each unknown sample were calculated by linear regression. Inhibition of the QPCR in sediment samples was accounted for by normalization to the internal pGEM plasmid standard (Coyne et al. 2005). The most concentrated standards for both the target and internal DNA samples were designated as the calibrator samples, which have a known concentration of target cells and provide a comparative basis for calculating cell abundances in unknown field samples (Coyne et al.
2005). The number of cells in each unknown sample was calculated using the following equation:

number of cells $=\left[(\text { target } / \text { pGEM })_{\text {unknown }} /\right.$ $\left.(\text { target/pGEM) })_{\text {calibrator }}\right] \times$ calibrator sample cell number

Finally, the concentration (cells $\mathrm{l}^{-1}$ or cysts $\mathrm{cm}^{-3}$ wet sediment) was calculated by multiplying the number of cells in the reaction by the dilution factor, and then dividing by the volume filtered or volume of wet sediment used in the extraction.

Calculating vegetative cells directly attributed to cyst germination. Since cells are capable of growth after germination, we calculated the minimum number of vegetative cells that could directly be attributed to cyst germination by subtracting the expected vegetative cell concentration (through cell division over time) from the total number of vegetative cells observed. Expected vegetative cell concentrations were calculated from the equation $B_{t}=B_{0} \mathrm{e}^{\mu \mathrm{t}}$, where $B_{0}$ is the initial concentration of cells (cells $\mathrm{l}^{-1}$, the number of cells from the previous time point), $B_{t}$ is the expected concentration of cells (cells $\mathrm{l}^{-1}$ ) at time $t(\mathrm{~d})$, and $\mu$ is the cell-specific growth rate for each of the Delaware strains of Heterosigma akashiwo and Chattonella subsalsa. Since the water in the replicate flasks of the laboratory experiments was diluted $15 \%$ after each sampling time point, $B_{0}$ was readjusted by subtracting the product of $B_{0}$ and 0.15 from the original $B_{0}$. Cell-specific growth rates $(\mu)$ for each species were calculated at each time point from recorded temperature, light, salinity, and nutrient $\left(\mathrm{PO}_{4}{ }^{3-}, \mathrm{NO}_{3}{ }^{-}\right.$, and $\left.\mathrm{NH}_{4}{ }^{+}\right)$concentrations using data available in Zhang et al. (2006). It was assumed that there were no losses due to grazing, which should yield an upper limit estimate for cells produced from vegetative growth. In field experiments, cell abundances were normalized to cells $\mathrm{l}^{-1}$, while in laboratory experiments abundances were normalized to cells flask $^{-1}$. Average vegetative cell abundances are represented as means \pm SD. In field experiments, correlations between detected germinated cells and dissolved nutrient concentrations $\left(\mathrm{PO}_{4}{ }^{3-}, \mathrm{NO}_{\mathrm{x}}{ }^{-}\right.$, and $\left.\mathrm{NH}_{4}{ }^{+}\right)$were tested with Pearson's correlation coefficient, using the statistical software SPSS (Version 15.0). In laboratory experiments, differences between germinated vegetative cells detected at different time points within each respective treatment were analyzed by a 1-way ANOVA, followed by a Tukey post hoc analysis.

Calculating cyst concentrations. To calculate the number of cysts within each mesocosm in the field experiments, the average concentration of detected cysts (cysts $\mathrm{cm}^{-3}$ wet sediment) in the sediment cores collected around the mesocosms was multiplied by the estimated volume $\left(1610 \mathrm{~cm}^{3}\right.$ wet sediment $)$ of the top $2 \mathrm{~cm}$ of sediments (sediment-water interface where germination would likely occur) within the mesocosm. 
To determine the number of cysts per treatment flask in the laboratory experiments, the average number of cysts $\mathrm{cm}^{-3}$ wet sediment was multiplied by the amount of sediment in each respective flask. Average cyst abundances are represented as means $\pm \mathrm{SD}$.

\section{RESULTS}

\section{Heterosigma akashiwo field germination experiment (FE-1)}

H. akashiwo cysts detected in FE-1 were highly variable between sediment cores, ranging from 187 to 2820 cysts $\mathrm{cm}^{-3}$ wet sediment, with an average of $2.7 \times$ $10^{6} \pm 2.2 \times 10^{6}$ cysts mesocosm ${ }^{-1}$ (Table 1 ). Germinated vegetative $H$. akashiwo cells from field experiments were first detected after $18 \mathrm{~d}$ (on April 4) in Mesocosms A and $\mathrm{C}$ and after $25 \mathrm{~d}$ (on April 11) in Mesocosm B and outside of the mesocosms (Fig. 3). By Day 18, water temperatures had increased from $10^{\circ} \mathrm{C}$ to $14-15^{\circ} \mathrm{C}$ and the salinity had decreased by as much as 5 to 15 within the mesocosms (Fig. 3). The majority of germinated

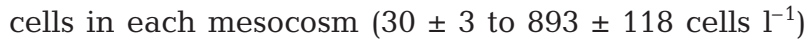
was detected when water temperatures increased to between 13 and $17^{\circ} \mathrm{C}$ and salinities were 6 to 15 (Fig. 3). A complete disappearance in vegetative $H$. akashiwo cells was observed in Mesocosm C on Day 20 , and large decreases in germinated cells were observed in and outside all 3 mesocosms on Day 28 (Fig. 3). In addition, meso- and microzooplankton protozoa were detected within and outside all 3 mesocosms by the end of the experiment (data not shown), although no direct grazing was observed through microscopic analysis of the collected water samples.

During FE-1, dissolved $\mathrm{PO}_{4}{ }^{3-}$ concentrations in Mesocosms A and B ranged from 0 to $0.65 \mu \mathrm{M}$ and were undetectable by the end of the experiment, while $\mathrm{NO}_{\mathrm{x}}{ }^{-}$(nitrate + nitrite) ranged from 11 to $81 \mu \mathrm{M}$ and

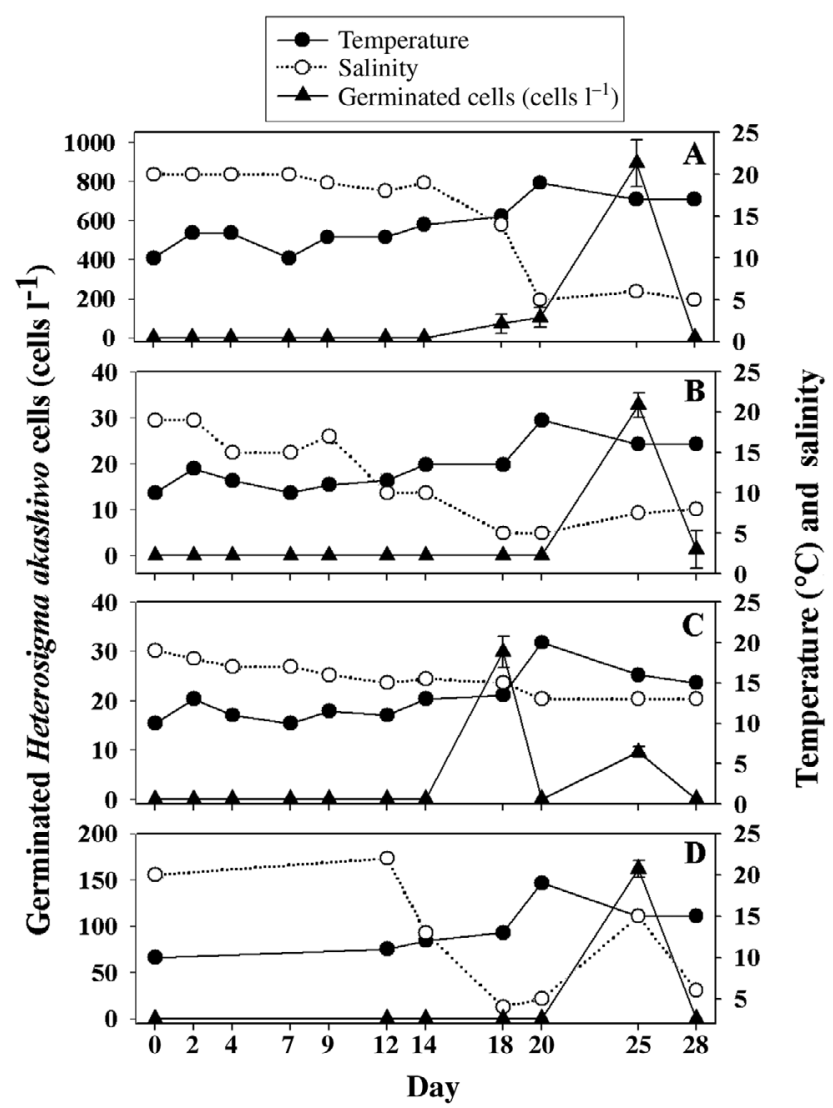

Fig. 3. Heterosigma akashiwo. Germinated vegetative cells (means $\pm \mathrm{SD})(\mathbf{\Lambda})$ in Field Experiment 1 over time $(28 \mathrm{~d})$ for each replicate mesocosm (A, B, and C) and outside the mesocosms (D). Corresponding temperatures (-) and salinities (O) are represented for each time point

$\mathrm{NH}_{4}{ }^{+}$ranged from 0.6 to $54 \mu \mathrm{M}$. In Mesocosm $\mathrm{C}, \mathrm{NO}_{\mathrm{x}}{ }^{-}$ became depleted by Day 7 and remained at low levels (1.2 to $7.6 \mu \mathrm{M})$ until the end of the experiment. No correlations were detected between dissolved nutrient concentrations and germinated Heterosigma akashiwo cells in any of the mesocosms.

Table 1. Heterosigma akashiwo and Chattonella subsalsa. Cyst abundances (cysts $\mathrm{cm}^{-3}$ wet sediment). Average cysts (mean $\pm \mathrm{SD}$ ) are represented for field experiments FE-1 and FE-2 (cysts mesocosm ${ }^{-1}$ ) and laboratory experiments LE-1 and LE-2 (cysts treatment flask ${ }^{-1}$ ). In total, 3 and 6 separate cores were examined for FE-1 and FE-2, respectively, while 6 sub-samples for each laboratory experiment were examined from homogenously mixed sediment. NA: not applicable; ND: not detected (indicating no cysts detected in the sample)

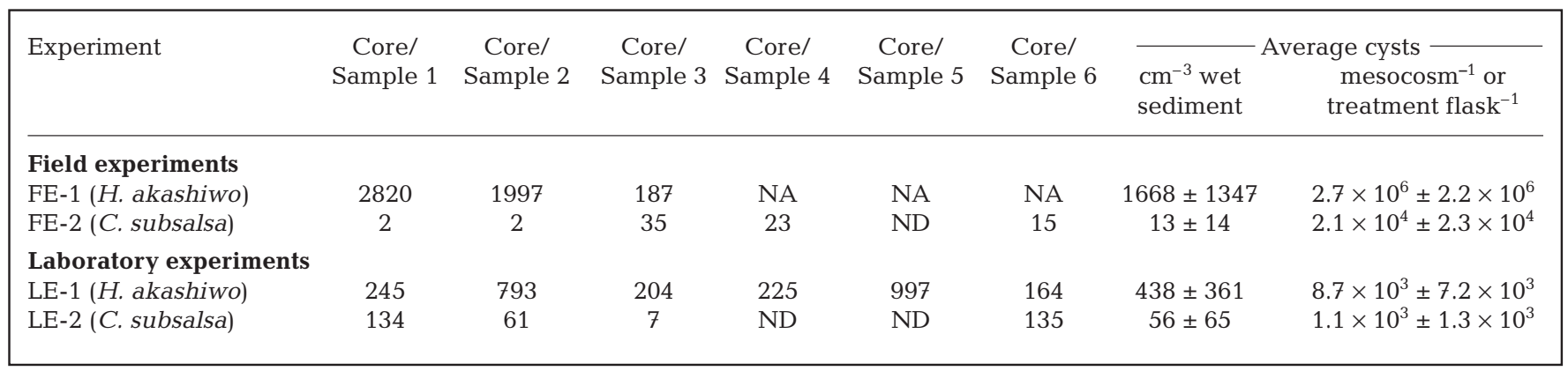




\section{Chattonella subsalsa field germination experiment (FE-2)}

C. subsalsa cysts within the sediment in FE-2 ranged from 0 (not detected) to 35 cysts $\mathrm{cm}^{-3}$ wet sediment, with an estimated average of $2.1 \times 10^{4} \pm 2.3 \times 10^{4}$ cysts mesocosm $^{-1}$ (Table 1). Vegetative C. subsalsa cells were first detected in low abundances $(21 \pm 9.4$ to $190 \pm$ 47 cells $^{-1}$ ) in all 3 mesocosms after $4 \mathrm{~d}$ (on May 13) and in low abundances $\left(86 \pm 34\right.$ cells l$^{-1}$ ) after $8 \mathrm{~d}$ (on May 17) outside the mesocosm (Fig. 4). By Day 4, water temperatures increased to $20^{\circ} \mathrm{C}$ and salinity was 25 (Fig. 4). The majority of germinated vegetative cells in all 3 mesocosms $\left(1460 \pm 271\right.$ to $7170 \pm 621$ cells l$\left.^{-1}\right)$ was detected after $28 \mathrm{~d}$, while most vegetative cells were detected outside of the mesocosms $\left(840 \pm 61\right.$ cells l$\left.^{-1}\right)$ after only 24 d (Fig. 4). By Day 28, water temperatures in the mesocosms had increased to $23^{\circ} \mathrm{C}$, with salinity ranging from 21 to 24 . Depletions in detected vegetative cells inside and outside all 3 mesocosms were observed from Day 8 through 18 (Fig. 4). Physicochemical parameters were similar inside and outside the mesocosms, with nutrient concentrations ranging from 0.1 to $0.8 \mu \mathrm{M}$ for $\mathrm{PO}_{4}{ }^{3-}, 0$ to $39 \mu \mathrm{M}$ for $\mathrm{NO}_{\mathrm{x}}{ }^{-}$, and 1 to 71

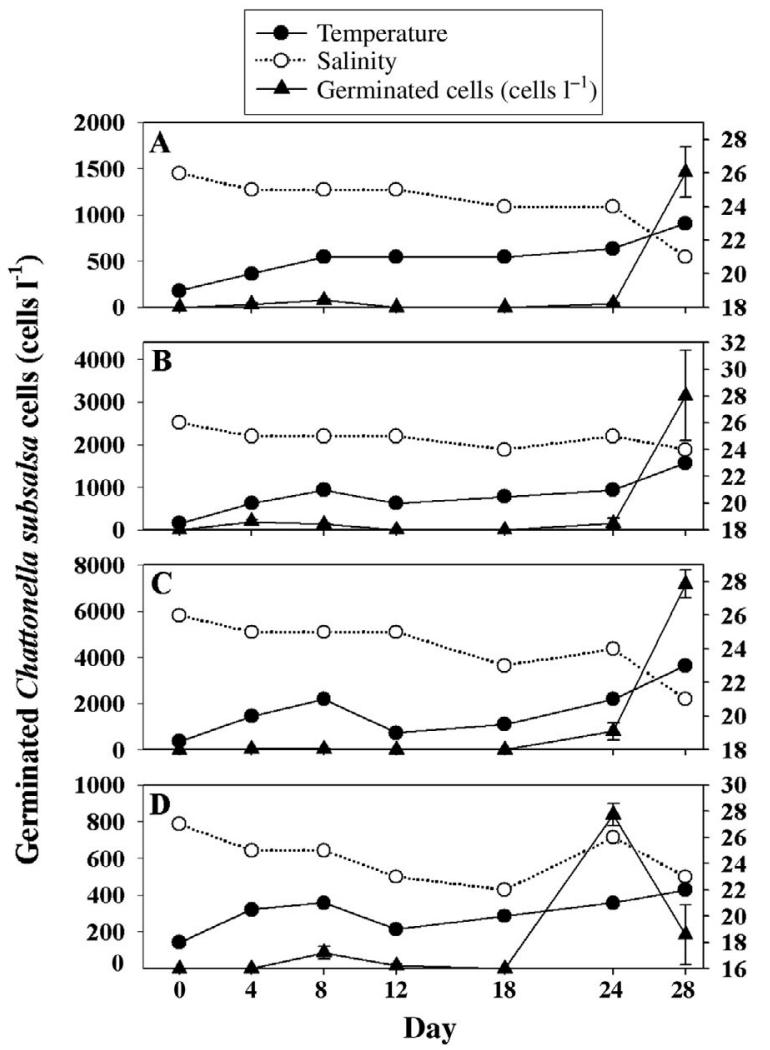

Fig. 4. Chattonella subsalsa. Germinated vegetative cells (means $\pm \mathrm{SD})(\boldsymbol{\Delta})$ in Field Experiment 2 over time $(28 \mathrm{~d})$ for each replicate mesocosm (A, B, and C) and outside the mesocosms (D). Corresponding temperatures (@) and salinities (O) are represented for each time point $\mu \mathrm{M}$ for $\mathrm{NH}_{4}{ }^{+}$. No correlations were detected between dissolved nutrient concentrations and germinated $C$. subsalsa cells.

\section{Heterosigma akashiwo laboratory germination experiment (LE-1)}

H. akashiwo cysts were abundant and highly variable within the homogenously mixed sediment used for LE-1, with concentrations between individual sediment sub-samples ranging from 164 to $997 \mathrm{cysts}^{-3}$ wet sediment and an average of $8.7 \times 10^{3} \pm 7.2 \times 10^{3}$ cysts flask ${ }^{-1}$ (Table 1). Germinated vegetative $H$. akashiwo cells were first detected after $11 \mathrm{~d}$ of incubation (Fig. $5 \mathrm{~A}$ ) at $10^{\circ} \mathrm{C}$ in both light and dark treatments $\left(55 \pm 63\right.$ and $2 \pm 4$ average cells flask ${ }^{-1}$, respectively), and after $21 \mathrm{~d}$ in the $20^{\circ} \mathrm{C}$ treatments $(25 \pm 26$ and $37 \pm$ 44 average cells flask $^{-1}$, for light and dark treatments, respectively). Germinated cells in the $10^{\circ} \mathrm{C}$ dark treatments were detected in only 1 replicate flask after $11 \mathrm{~d}$ (Fig. 5A) and only in small numbers ( 7 cells flask ${ }^{-1}$ ) compared to the abundance in the other treatments.

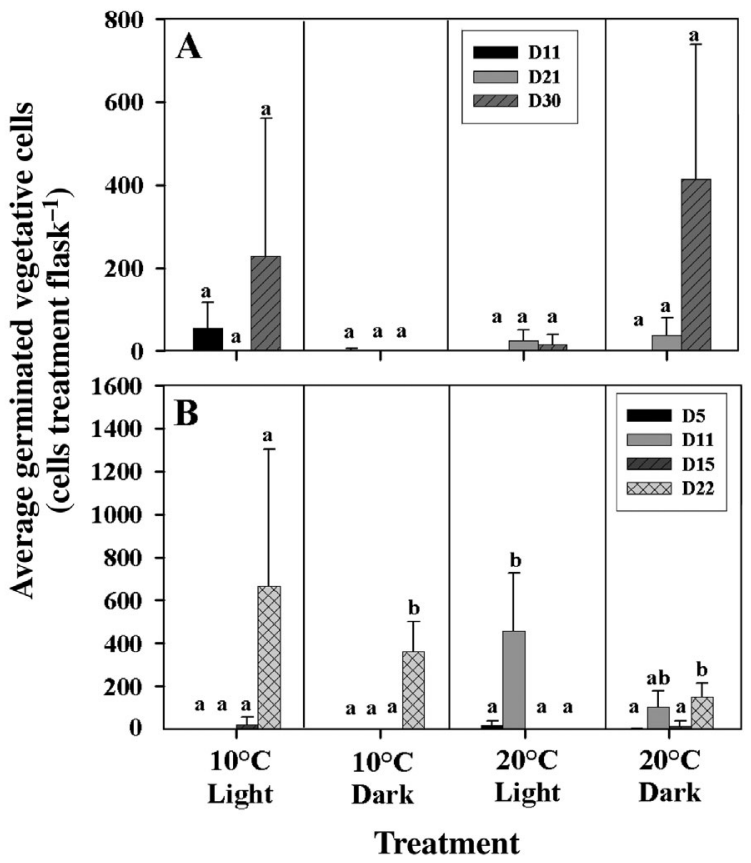

Fig. 5. Heterosigma akashiwo and Chattonella subsalsa. Average germinated vegetative cells per treatment flask (mean $\pm \mathrm{SD}$ ) for (A) Laboratory Experiment 1 with $H$. akashiwo and (B) Laboratory Experiment 2 with C. subsalsa, in 4 separate treatments, respectively: $10^{\circ} \mathrm{C}$ in $55 \mu \mathrm{mol}$ photons $\mathrm{m}^{-2} \mathrm{~s}^{-1}$ light, $10^{\circ} \mathrm{C}$ in total darkness, $20^{\circ} \mathrm{C}$ in $55 \mu \mathrm{mol}$ photons $\mathrm{m}^{-2} \mathrm{~s}^{-1}$ light, and $20^{\circ} \mathrm{C}$ in total darkness. D5 to D30: days after the start of the experiment on which water samples were collected. Columns labeled with the same lower case letter within each respective treatment for each experiment are not significantly different $(p>0.05)$ 


\section{Chattonella subsalsa laboratory germination experiment (LE-2)}

Initial C. subsalsa cyst concentrations within the sediments used in LE-2 ranged from 0 (not detected) to 135 cysts $\mathrm{cm}^{-3}$ wet sediment (Table 1). Average $C$. subsalsa cyst abundances for LE- 2 were $56 \pm 65$ cysts $\mathrm{cm}^{-3}$ wet sediment $\left(1.1 \times 10^{3} \pm 1.3 \times 10^{3}\right.$ cysts flask $^{-1}$; Table 1). Germinated vegetative C. subsalsa cells were first detected after $5 \mathrm{~d}$ in low abundances in both the $20^{\circ} \mathrm{C}$ light and dark treatments $(18 \pm 21$ and $1.8 \pm 2.0$ cells flask ${ }^{-1}$, respectively; Fig. 5B). The majority of germinated cells in the $20^{\circ} \mathrm{C}$ light treatments $(457 \pm 269$ cells flask ${ }^{-1}$ ) occurred by Day 11, while germination continued over the entire experiment in the dark treatments at $20^{\circ} \mathrm{C}$ (Fig. 5B). C. subsalsa germination was detected in high numbers in the $10^{\circ} \mathrm{C}$ light and dark treatments $\left(667 \pm 637\right.$ and $360 \pm 142$ cells flask ${ }^{-1}$, respectively) after $22 \mathrm{~d}$ (Fig. 5B).

\section{DISCUSSION}

Rising temperatures to $\geq 15^{\circ} \mathrm{C}$ have been shown to stimulate the germination of Heterosigma akashiwo in previous studies (Yamochi 1984, Imai \& Itakura 1999, Shikata et al. 2007). In the present study, although the majority of $H$. akashiwo germination occurred in situ when water temperatures increased to $13-17^{\circ} \mathrm{C}$, germination did not appear to be affected by the different temperatures $\left(10\right.$ and $\left.20^{\circ} \mathrm{C}\right)$ used in our laboratory studies. Germination of $H$. akashiwo has been observed in other studies at low temperatures of 5 and $8^{\circ} \mathrm{C}$ (Shikata et al. 2007), 9.8 ${ }^{\circ} \mathrm{C}$ (Yamochi 1984), and $10^{\circ} \mathrm{C}$ (Imai \& Itakura 1999), although this germination was limited when compared to that at higher temperatures. In the present study, substantial reduction in germination of $H$. akashiwo was not observed at lower temperatures $\left(10^{\circ} \mathrm{C}\right)$ in the light, indicating that local Delaware strains may be more adapted to germination at low temperatures. This appears consistent with Delaware strains of $H$. akashiwo that are capable of vegetative growth over a wide temperature range of 4 to $30^{\circ} \mathrm{C}$ (Zhang et al. 2006), suggesting that germination and cell survival may be possible even at lower temperatures than those used in the present study. Detection of vegetative $H$. akashiwo cells has been well documented in coastal waters at temperatures as low as $2.9^{\circ} \mathrm{C}$ in Narragansett Bay, Rhode Island (Tomas 1980), $4^{\circ} \mathrm{C}$ in Norwegian coastal waters (Smayda 1998), and $5.8^{\circ} \mathrm{C}$ in Osaka Bay, Japan (Yamochi 1984). With the ability to germinate and survive as vegetative cells at these low temperatures, H. akashiwo could potentially have an advantage earlier in the season among other cyst-forming phytoplankton species that may need higher temperatures for germination. However, since $H$. akashiwo has reduced growth at temperatures $\leq 10^{\circ} \mathrm{C}$ (Tomas 1978, Zhang et al. 2006) and does not usually form blooms until temperatures have reached 15 to $20^{\circ} \mathrm{C}$ (Smayda 1998), it is unlikely that these early germinated cells will propagate to bloom concentrations under conditions unfavorable for rapid growth.

Delaware strains of Heterosigma akashiwo demonstrated the ability to germinate in the dark without any light stimulus, similar to previous studies (Imai et al. 1996, Shikata et al. 2007). This ability to germinate in the dark may provide selective advantages over phytoplankton, such as diatoms, that require light for germination (Imai et al. 1996). However, warmer temperatures may be essential for germination in the absence of light, as germination was detected in only low abundances in the dark at lower temperatures $\left(10^{\circ} \mathrm{C}\right) \mathrm{com}-$ pared to those in the dark at higher temperatures $\left(20^{\circ} \mathrm{C}\right)$. Further, Shikata et al. (2007) suggested that light and warm temperature play a crucial role in the survival and transition of newly germinated $H$. akashiwo cells to a mature vegetative state. Therefore, germination may have proceeded in our $10^{\circ} \mathrm{C}$ treatments in the dark, but these cells may not have survived to grow to mature vegetative cells in these conditions, and therefore would not be detected in the sampled water.

Although low-salinity events coincided with Heterosigma akashiwo germination in situ, it does not appear that salinity restricts $H$. akashiwo germination and vegetative cell survival, since germination occurred over a wide range of salinities (6 to 25) in the present study. Zhang et al. (2006) has further demonstrated that the Delaware strain of H. akashiwo is euryhaline and can grow at salinities ranging from 5 to 30 , with optimal salinity ranges between 10 and 30 . Although salinity has been shown not to have any inhibitory effects on the germination of many dominant diatom and dinoflagellate resting cells, such as in species of Chaetoceros, Skeletonema, Thalassiosira, and Scrippsiella, salinity does significantly affect the growth of all these groups after germination (McQuoid 2005). Therefore, the ability of $H$. akashiwo to tolerate and grow at wide salinity ranges may be advantageous during the spring and early summer, when frequent rainfall events may prevent more stenohaline species from germinating or proliferating in the water column.

Shikata et al. (2007) found that Heterosigma akashiwo has the ability to germinate independent of light and temperature if the cysts are suspended in seawater. It is possible that the initial sediment mixing to create homogenously mixed sediment samples in our laboratory experiments may have stimulated germination of $H$. akashiwo, since small numbers of germi- 
nated cells were detected in the $10^{\circ} \mathrm{C}$ dark treatments without a temperature or a light stimulus. However, since the sediments in our laboratory experiments were not continually mixed throughout the entire experiment, as conducted by Shikata et al. (2007), it is unlikely that initial mixing at the beginning of our studies had a significant effect on $H$. akashiwo cyst germination.

Heterosigma akashiwo may germinate in response to an internal biological control, which has been suggested for phytoplankton cysts that germinate in the absence of any changing physical cues (Anderson \& Keafer 1987), such as temperature or light. Li \& Smayda (2000) have conducted weekly collections for 38 yr in Narragansett Bay, Rhode Island, and have observed the first appearances of $H$. akashiwo in the water column to regularly occur during mid-May. Although temperature was suspected of significantly influencing the recruitment of vegetative cells into the water column, the consistency in $H$. akashiwo appearance during the same period over $38 \mathrm{yr}$ suggests that germination may be partially regulated by an endogenous control. However, more research on the possible regulation of germination by endogenous control is needed to fully understand this process.

Temperature may be an important germination trigger for the Delaware strain of Chattonella subsalsa. Warmer temperatures appear to stimulate germination, since the majority of C. subsalsa cells germinated in situ at $23^{\circ} \mathrm{C}$, similar to optimal germination temperatures $\left(20\right.$ to $25^{\circ} \mathrm{C}$ ) for $C$. antiqua, C. marina, and $C$. ovata (Imai et al. 1984a, 1991). However, our studies also show that low temperatures $\left(10^{\circ} \mathrm{C}\right)$ did not prevent the germination of $C$. subsalsa in laboratory experiments, although germination was delayed when compared to the higher temperature treatments. Since germination of $C$. marina and $C$. antiqua has not been observed at temperatures $\leq 10^{\circ} \mathrm{C}$ (Imai et al. 1991), $C$. subsalsa may germinate over a wider germination temperature range than these closely related species. Furthermore, C. subsalsa was observed to germinate in the dark, which is consistent with other species of Chattonella (Imai et al. 1984a). Therefore, germination of C. subsalsa under low light and low temperatures could provide a distinct advantage for this species over other phytoplankton, such as dinoflagellates or diatom species that require light for germination (Binder \& Anderson 1986, Anderson et al. 1987, Imai et al. 1996). However, since $C$. subsalsa growth rates are highly reduced at temperatures of $\leq 10^{\circ} \mathrm{C}$ and low light levels (Zhang et al. 2006), it is unlikely that these initial germination events will lead to blooms early in the year. Since C. subsalsa germination was only observed at salinities between 21 and 27 in the present study, it has not been determined whether C. subsalsa can germi- nate over the same broad salinity range as Heterosigma akashiwo. However, C. subsalsa has been shown to tolerate a wide salinity range (5 to 36 ) in its vegetative state (Zhang et al. 2006) if germination proceeds in low-salinity waters.

Even if germinated cells can overcome temperature constraints on cell survival, both Heterosigma akashiwo and Chattonella subsalsa must still overcome significant obstacles from microzooplankton grazing and interspecific competition (Imai et al. 1996, Smayda 1998) in order to proliferate in the water column. Significant grazing by copepods and heterotrophic dinoflagellates on Chattonella spp. has been well documented (Uye 1986, Nakamura 1992). Demir et al. (2008) further observed significant grazing on $H$. akashiwo from microzooplankton in the DIBs, suggesting that, at least in our field experiments, vegetative cell concentrations of $C$. subsalsa and $H$. akashiwo may have been reduced due to grazing pressure. Active grazing may explain substantial decreases in detected cell abundances in our mesocosms. Even under conditions where there is limited microzooplankton grazing, competition for the available nutrients required for growth with other phytoplankton species, such as the diatom Skeletonema costatum, may also significantly affect the survival and proliferation of H. akashiwo (Smayda 1998) and C. subsalsa. Although few other algal species were observed as vegetative cells in either our field or laboratory experiments, competing algal species in situ have the potential to sequester valuable nutrients necessary for growth, thus limiting early seasonal growth of raphidophytes.

Raphidophyte cysts do not appear to be evenly distributed within environmental sediments, as high variability in cyst abundances was observed between sediment cores and between homogenized sub-samples within each respective experiment. This variability in cyst abundance may be partly explained by cysts adhering to one another and forming clumps within sediments. Both Heterosigma akashiwo and Chattonella subsalsa have been observed to form nonmotile plasmodial masses encapsulated by mucilage (Tomas 1978, authors' pers. obs.) in both natural environmental samples and laboratory flasks. The uneven distribution of algal cysts caused by the adherence of cysts to one another or to sediments may complicate accurate homogenization of sediment samples, and therefore must be considered in germination studies using QPCR in order to obtain an accurate representation of the natural cyst community.

Traditional approaches for quantifying raphidophyte cysts within sediments rely on either an indirect approach (most probable number method; Imai et al. 1984b, Imai \& Itakura 1999) or direct approaches such 
as sieving out phytoplankton cysts (Anderson et al. 2003). However, sieving techniques may be destructive to more fragile raphidophyte species, particularly Heterosigma akashiwo, whose resting stages are not known to form a protective cell wall (Han et al. 2002). Therefore, the molecular tools employed in the present study offer a direct approach to quantifying raphidophyte cysts within sediments. QPCR also proved to be an invaluable tool for detecting low quantities of newly germinated $H$. akashiwo and Chattonella subsalsa cells in the water column. In the DIBs, the first germinated $H$. akashiwo and C. subsalsa cells of the season are consistently detected by microscopic identification during May and June, respectively (Whereat 2002-2006). Our initial detection of vegetative $H$. akashiwo and C. subsalsa cells inside and outside mesocosms from early to mid-April and mid-May, respectively, illustrates how QPCR has enabled us to detect early germination events for these species. Therefore, water monitoring strategies employed earlier in the year using QPCR may provide valuable information on initial germination events of harmful algal cysts into the water column.

Accurate detection of newly germinated raphidophyte cells in water samples and cysts within natural sediments is essential for successful monitoring of potential algal blooms using the QPCR technique. Coyne et al. (2005) previously demonstrated the accuracy of QPCR in detecting Delaware strains of both Heterosigma akashiwo and Chattonella subsalsa from natural water samples, with detected cell count differences within an order of magnitude compared to cell counts quantified by traditional microscopy. Even though molecular tools are extremely sensitive and accurate in enumerating vegetative cells from water samples, detection of cysts within natural sediments using QPCR is further complicated with numerous inhibiting substances abundant in sediments, such as humic acids (Wilson 1997), which can prevent or reduce the efficiency of PCR amplification, especially in samples with low quantities of target DNA. Our use of the internal standard pGEM minimizes the possible variability in DNA extraction and variations in PCR efficiencies caused by these inhibitors (Coyne et al. 2005). However, since QPCR only detects DNA extracted from cells, it is possible that some of these cells may no longer be viable and therefore may cause an overestimation of the potential germinable cyst population. In addition, because $C$. subsalsa cyst abundances were calculated from a standard curve generated from vegetative cells, the actual number of $C$. subsalsa cysts calculated in this experiment may be underestimated due to ploidy differences in DNA content of different life stages. If C. subsalsa vegetative cells are diploid in DNA content and the cysts haploid, as in the case of $C$. antiqua and $C$. marina (Yamaguchi \& Imai 1994), then the number of C. subsalsa cysts calculated in this experiment would increase by a factor of 2 .

Examining raphidophyte life-history stages and physical cues affecting cyst germination may further help to identify factors that contribute to bloom initiation. By using QPCR to detect and quantify algal cysts and germinated vegetative cells, we were able to evaluate germination cues for Heterosigma akashiwo and Chattonella subsalsa and provide a direct in situ examination of germinated raphidophytes and cysts from natural sediments. Future research efforts are now poised to examine the contribution of germinated cysts to the development of blooms later in the spring and summer seasons.

Acknowledgements. We acknowledge USA EPA-ECOHAB STAR Grant 8310401 (to D.A.H., S.C.C., and K.J.C.), Center for the Inland Bays Grant EPA 99399-008-2 (to S.C.C. and K.J.P.), and a Delaware EPSCoR graduate research fellowship to K.J.P. Thanks to G. Luther, D. Miller, E. Whereat, J. Scudlark, Y. Zhang, M. Warner, T. Moore, R. Dale, E. Demir, and the DE Phytoplankton Monitoring Group for assistance with experimental design, data collection and analysis, or interpretation of results. Thanks to M. Chofsky and B. Winkler for extensive use of their docks for field sampling.

\section{LITERATURE CITED}

Anderson DM, Keafer BA (1987) An endogenous annual clock in the toxic marine dinoflagellate Gonyaulax tamarensis. Nature 325:616-617

Anderson DM, Taylor CD, Armbrust EV (1987) The effects of darkness and anaerobiosis on dinoflagellate cyst germination. Limnol Oceanogr 32:340-351

Anderson DM, Fukuyo Y, Matsuoka K (2003) Cyst methodologies. In: Hallegraeff G, Anderson DM, Cembella A (eds) Manual on harmful marine microalgae. UNESCO, Landis, p 165-189

Binder BJ, Anderson DM (1986) Green light-mediated photomorphogenesis in a dinoflagellate resting cyst. Nature 322:659-661

Coyne KJ, Hutchins DA, Hare CE, Cary SC (2001) Assessing temporal and spatial variability in Pfiesteria piscicida distributions using molecular probing techniques. Aquat Microb Ecol 24:275-285

Coyne KJ, Handy SM, Demir E, Whereat EB and others (2005) Improved quantitative real-time PCR assays for enumeration of harmful algal species in field samples using an exogenous DNA reference standard. Limnol Oceanogr Methods 3:381-391

Demir E, Coyne KJ, Doblin MA, Handy SM, Hutchins DA (2008) Assessment of microzooplankton grazing on Heterosigma akashiwo using a species-specific approach combining quantitative real-time PCR (QPCR) and dilution methods. Microb Ecol 55:583-594

> Dempster EL, Pryor KV, Francis D, Young JE, Rogers HJ (1999) Rapid DNA extraction from ferns for PCR-based analyses. Biotechniques 27:66-68

Guillard RRL (1975) Culturing of phytoplankton for feeding marine invertebrates. In: Smith WL, Chanley MH (eds) 
Culturing marine invertebrate animals. Plenum Publishing, New York, p 29-60

Han MS, Kim YP, Cattolico RA (2002) Heterosigma akashiwo (Raphidophyceae) resting cell formation in batch culture: strain identity versus physiological response. J Phycol 38:304-317

> Handy SM, Coyne KJ, Portune KJ, Demir E and others (2005) Evaluating vertical migration behavior of harmful raphidophytes in the Delaware Inland Bays utilizing quantitative real-time PCR. Aquat Microb Ecol 40:121-132

Honjo T (1993) Overview on bloom dynamics and physiological ecology of Heterosigma akashiwo. In: Smayda TJ, Shimizu Y (eds) Toxic phytoplankton blooms in the sea. Elsevier, New York, p 33-41

Imai I, Itakura S (1999) Importance of cysts in the population dynamics of the red tide flagellate Heterosigma akashiwo (Raphidophyceae). Mar Biol 133:755-762

Imai I, Itoh K (1987) Annual life cycle of Chattonella spp., causative flagellates of noxious red tides in the Inland Sea of Japan. Mar Biol 94:287-292

Imai I, Itoh K, Anraku M (1984a) Distribution of dormant cells of Chattonella in Harima-Nada, eastern Seto Inland Sea, and temperature characteristics of germination. Bull Plankton Soc Japan 31:35-42

Imai I, Itoh K, Anraku M (1984b) Extinction dilution method for enumeration of dormant cells of red tide organisms in marine sediments. Bull Plankton Soc Japan 31:123-124

Imai I, Itoh K, Anraku M (1989) Dormancy and maturation in the cysts of Chattonella spp. (Raphidophyceae), red tide flagellates in the Inland Sea of Japan. In: Okaichi T, Anderson DM, Nemoto T (eds) Red tides: biology, environmental science, and toxicology. Elsevier Science Publishing, New York, p 289-292

Imai I, Itakura S, Itoh K (1991) Life cycle strategies of the red tide causing flagellates Chattonella (Raphidophyceae) in the Seto Inland Sea. Mar Pollut Bull 23:165-170

Imai I, Itakura S, Itoh K (1993) Cysts of the red tide flagellate Heterosigma akashiwo, Raphidophyceae, found in bottom sediments of northern Hiroshima Bay, Japan. Nippon Suisan Gakk 59:1669-1673

Imai I, Itakura S, Yamaguchi M, Honjo T (1996) Selective germination of Heterosigma akashiwo (Raphidophyceae) cysts in bottom sediments under low light conditions: a possible mechanism of red tide initiation. In: Yasumoto $\mathrm{T}$, Oshima Y, Fukuyo Y (eds) Harmful and toxic algal blooms. Intergovernmental Oceanographic Commission of UNESCO, Paris, p 197-200

Imai I, Yamaguchi M, Watanabe M (1998) Ecophysiology, life cycle, and bloom dynamics of Chattonella in the Seto Inland Sea, Japan. In: Anderson DM, Cembella A, Hallegraeff G (eds) Physiological ecology of harmful algal blooms. Springer-Verlag, Berlin, p 95-111

Itakura S, Nagasaki K, Yamaguchi M, Imai I (1996) Cyst formation in the red tide flagellate Heterosigma akashiwo (Raphidophyceae). J Plankton Res 18:1975-1979

Li Y, Smayda TJ (2000) Heterosigma akashiwo (Raphidophyceae): on prediction of the week of bloom initiation and maximum during the initial pulse of its bimodal bloom cycle in Narragansett Bay. Plankton Biol Ecol 47:80-84

McQuoid MR (2005) Influence of salinity on seasonal germination of resting stages and composition of microplank-

Editorial responsibility: Dittmar Hahn,

San Marcos, Texas, USA ton on the Swedish west coast. Mar Ecol Prog Ser 289:151-163

Nakamura Y, Yamazaki Y, Hiromi J (1992) Growth and grazing of a heterotrophic dinoflagellate, Gyrodinium dominans, feeding on a red tide flagellate, Chatonella antiqua. Mar Ecol Prog Ser 82:275-279

Okaichi T (1989) Red tide problems in the Seto Inland Sea, Japan. In: Okaichi T, Anderson DM, Nemoto T (eds) Red Tides: biology, environmental science, and toxicology. Elsevier, New York, p 137-142

Park JS, Kim HG, Lee SG (1989) Studies on red tide phenomena in Korean coastal waters. In: Okaichi T, Anderson DM, Nemoto T (eds) Red tides: biology, environmental science, and toxicology. Elsevier, New York, p 37-40

Shikata T, Nagasoe S, Matsubara T, Yamasaki Y, Shimasaki Y, Oshima Y, Honjo T (2007) Effects of temperature and light on cyst germination and germinated cell survival of the noxious raphidophyte Heterosigma akashiwo. Harmful Algae 6:700-706

Smayda TJ (1998) Ecophysiology and bloom dynamics of Heterosigma akashiwo (Raphidophyceae). In: Anderson DM, Cembella AD, Hallegraeff GM (eds) Physiological ecology of harmful algal blooms, Vol G41. Springer-Verlag, Berlin, p 113-131

Tomas CR (1978) Olisthodiscus luteus (Chrysophyceae). 2. Formation and survival of a benthic stage. J Phycol 14: $314-319$

Tomas CR (1980) Olisthodiscus luteus (Chrysophyceae). 5. Its occurrence, abundance and dynamics in Narragansett Bay, Rhode Island. J Phycol 16:157-166

Uye S (1986) Impact of copepod grazing on the red tide flagellate Chatonella antiqua. Mar Biol 92:35-43

Whereat ED (2002-2006) Phytoplankton monitoring reports. Volunteer Phytoplankton Monitoring Group, Inland Bays Monitoring Program, University of Delaware SGMAS, Lewes, DE

Wilson IG (1997) Inhibition and facilitation of nucleic acid amplification. Appl Environ Microbiol 63:3741-3751

Yamaguchi M, Imai I (1994) A microfluorometric analysis of nuclear DNA at different stages in the life history of Chattonella antiqua and Chattonella marina (Raphidophyceae). Phycologia 33:163-170

Yamaguchi M, Yamaguchi H, Nishitani G, Sakamoto S, Itakura S (2008) Morphology and germination characteristics of the cysts of Chattonella ovata (Raphidophyceae), a novel red tide flagellate in the Seto Inland Sea, Japan. Harmful Algae 7:459-463

Yamochi S (1984) Mechanisms for outbreak of Heterosigma akashiwo red tide in Osaka Bay, Japan, Part 3. Release of vegetative cells from bottom mud. J Oceanogr Soc Jpn 40:343-348

Yamochi S (1989) Mechanisms for outbreak of Heterosigma akashiwo red tide in Osaka Bay, Japan. In: Okaichi T, Anderson DM, Nemoto T (eds) Red tides: biology, environmental science, and toxicology. Elsevier, New York, p 253-256

Zhang YH, Fu FX, Whereat E, Coyne KJ, Hutchins DA (2006) Bottom-up controls on a mixed-species HAB assemblage: a comparison of sympatric Chattonella subsalsa and Heterosigma akashiwo (Raphidophyceae) isolates from the Delaware Inland Bays, USA. Harmful Algae 5:310-320

Submitted: November 6, 2008; Accepted: February 24, 2009

Proofs received from author(s): April 27, 2009 